\title{
Harapan Dan Tantangan Implementasi Pembelajaran IPA Dalam Konteks Kompetensi Keterampilan Abad 21 Di Sekolah Menengah Pertama
}

\author{
Yayuk Andayani $^{1}$, Nyoman Sridana ${ }^{2}$, Kosim $^{3}$, Dadi Setiadi ${ }^{4}$, Gito Hadiprayitno ${ }^{5}$
}

${ }^{1-5}$ Program Studi Magister Pendidikan IPA, Program Pascasarjana.

*Corresponding Author: Yayuk Andayani, Program Studi Magister Pendidikan IPA, Program Pascasarjana.;

Email: yayukmtr@unram.ac.id.

\begin{abstract}
Abstrak: Ketrampilan Abad 21 yang dianggap bisa memperkuat modal social (social capital) dan modal intelektual (intellectual capital) ini, biasa disingkat dengan $4 \mathrm{C}$ : communication, collaboration, critical thinking and problem solving, dan creativity and innovation. Secara operasional, 4C ini dapat dijabarkan sebagai cara berpikir, termasuk berkreasi, berinovasi, bersikap kritis, memecahkan masalah, membuat keputusan, dan belajar proaktif. Juga termasuk cara bekerja, termasuk berkomunikasi, berkolaborasi, bekerja dalam tim sehungga dapa mendukung dan mengembangkan ketrampilan abad 21, yakni teknologi informasi, jaringan digital, dan literasi. Konsep 4C ini diharapkan dapat diimplementasikan di sekolah-sekolah dan para peserta didik Indonesia terbekali dengan keutamaan-keutamaan tersebut, yakni komunikasi, kolaborasi, berpikir kritis dan pemecahan masalah, serta kreatif dan inovatif. Kegiatan pembelajaran IPA di Sekolah Menengah Pertamadiharapkan mampu memberdayakan semua potensi peserta didik untuk mendorong pencapaian kompetensi dan perilaku khusus supaya setiap individu mampu menjadi pembelajar sepanjang hayat dan mewujudkan masyarakat belajar. Dengan demikianguru diharapkan mampu mengimplementasikan metode pembelajaran yang inovatif (studentscentered), maka peran guru tidak lagi sebagai pentransfer ilmu, melainkan sebagai fasilitator atau membantu siswa agar siswa mampu menguasai berbagai kompetensi yang diharapkan.
\end{abstract}

Kata Kunci: Pembelajaran IPA, Kompetensi Keterampilan Abad 21, Kurikulum 2013

keempat, alat untuk mengembangkan ketrampilan abad 21, yakni teknologi informasi, jaringan digital, dan literasi. Bayangkan bila konsep ini bisa dijalankan di sekolah-sekolah dan para peserta didik Indonesia terbekali dengan keutamaankeutamaan tersebut, yakni komunikasi, kolaborasi, berpikir kritis dan pemecahan masalah, serta kreatif dan inovatif.

Senada dengan yang diuraikan Morocco, et al. di atas, secara lebih komprehensif Trillingand Fadel (2009: 47) menggagas konsep pelangi keterampilan dan pengetahuan sebagai subjek inti atau kompetensi utama yang harus dikembangkan dalam konteks pendidikan abad ke-21.Pelangi keterampilan dan pengetahuan tersebut disajikan dalam gambar 1.2 berikut. 


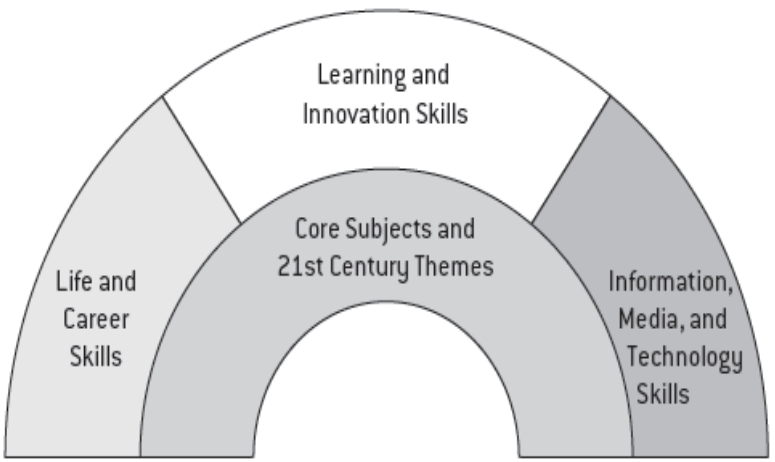

Gambar 1

Pelangi Keterampilan dan Pengetahuan Abad Ke21

(Trilling\& Fadel, 2009: 47)

Berdasarkan pelangi keterampilan dan pengetahuan yang dikembangkannya, Trilling \& Fadel (2009: 48) menjelaskan bahwa keterampilan utama yang harus dimiliki dalam konteks abad ke21 adalah keterampilan belajar dan berinovasi. Keterampilan ini berkenaan dengan kemampuan berpikir kreatif dan kemampuan memecahkan masalah, kemampuan berkomunikasi dan berkolaborasi, dan kemampuan untuk berkreativitas dan berinovasi. Ketrampilan-keterampilan ini diyakini merupakan keterampilan utama yang dapat menjawab berbagai tantangan hidup baik dari dimensi ekonomi, sosial, politik maupun dimensi pendidikan. Oleh sebab itu, proses pembelajaran hendaknya diorientasikan untuk membekali peserta didik dengan keterampilan- keterampilan tersebut di samping membekali peserta didik dengan pengetahuan keilmuan tertentu.

Kemampuan berpikir kreatif dan kemampuan memecahkan masalah sebagai salah satu orientasi pembelajaran modern secara lebih luas akan membekali peserta didik dengan keterampilan lain yang lebih kecil yang melingkupinya. Keterampilan dimaksud adalah keterampilan menggunakan berbagai alasan secara efektif, keterampilan berpikir secara sistemik, keterampilan mempertimbangkan dan membuat keputusan, dan keterampilan memecahkan masalah. Keterampilan berkomunikasi dan berkolaborasi dimaksudkan untuk membekali peserta didik agar mampu berkomunikasi untuk berbagai tujuan secara jelas dan efektif, baik dalam hal berbicara, menulis, membaca, maupun menyimak dan membekali peserta didik agar mampu berkolaborasi dengan orang lain sehingga peserta didik akan mampu bekerja secara efektif dalam kelompok, melakukan negosiasi secara efektif, dan mampu menghargai peran orang lain dalam kelompoknya. Kemampuan berkreativitas dan berinovasi dimaksudkan untuk membekali peserta didik agar mampu berpikir kreatif, bekerja kreatif dengan orang lain, dan mampu menghasilkan berbagai inovasi.

Berdasarkan kompetensi ketrampilan abad ke-21 sebagai dikemukakan beberapa ahli di atas, Kemendikbud melakukan sejumlah terobosan guna meningkatkan mutu pendidikan agar mampu menghasilkan lulusan yang siap bersaing secara global di masa yang akan datang. Salah satu terobosan awal tersebut adalah dengan memberlakukan kurikulum 2013. Dengan kata lain, pemberlakuan kurikulum 2013 ditujukan untuk menjawab tantang zaman terhadap pendidikan yakni untuk menghasilkan lulusan yang kompetitif, inovatif, kreatif, kolaboratif serta berkarakter. Guna mencapai orientasi akhirnya ini, disadari benar bahwa pendidikan bukan hanya dilakukan untuk mengembangkan pengetahuan berdasarkan subjek inti pembelajaran melainkan juga harus diorientasikan agar peserta didik memiliki kemampuan kreatif, kritis, komunikatif sekaligus berkarakter.

Upaya pengembangan kurikulum 2013 yang lebih baik tidak hanya dilakukan dengan sekali jadi. Sejak diberlakukan pada tahun 2013, setidaknya telah dilakukan penyempurnaan sebanyak tiga kali yakni para tahun 2014, 2016, dan 2017. Penyempurnaan kurikulum 2013 tersebut ditujukan agar kurikulum yang dikembangkan benar-benar sejalan dengan kondisi dan kebutuhan peserta didik Indonesia sehingga diharapkan mampu menghasilkan Generasi Indonesia Emas pada tahun 2045. Pada tahun 2017 sebagai salah satu program utama Kemendikbud dalam mengembangkan mutu sumber daya manusia Indonesia di masa yang akan datang.

\section{Pembahasan}

\section{Pembelajaran IPA Abad 21}

Kementerian Pendidikan dan Kebudayaan menerapkan Kurikulum 2013 Revisi 2017. Kurikulum ini diharapkan sudah menjawab kritik dan masalah ketika Kurikulum 2013 (Kurtilas) diberlakukan. Yang pasti, Kurikulum 2013 dan juga Revisi 2017 tetap menegaskan mengenai pentingnya Ketrampilan Abad 21. Tulisan ini membahas mengenai implementasi Ketrampilan Abad 21 itu. 
Ketrampilan Abad 21 yang dianggap bisa memperkuat modal social (social capital) dan modal intelektual (intellectual capital) ini, biasa disingkat dengan 4C: communication, collaboration, critical thinking and problem solving, dan creativity and innovation. Secara operasional, 4C ini dijabarkan dalam empat kategori langkah, yakni: Pertama, cara berpikir, termasuk berkreasi, berinovasi, bersikap kritis, memecahkan masalah, membuat keputusan, dan belajar pro-aktif. Kedua, cara bekerja, termasuk berkomunikasi, berkolaborasi, bekerja dalam tim. Ketiga, cara hidup sebagai warga global sekaligus local; dan keempat, alat untuk mengembangkan ketrampilan abad 21, yakni teknologi informasi, jaringan digital, dan literasi,

Bayangkan bila konsep ini bisa dijalankan di sekolah-sekolah dan para Peserta Didik Indonesia terbekali dengan keutamaan-keutamaan tersebut, yakni komunikasi, kolaborasi, berpikir kritis dan pemecahan masalah, serta kreatif dan inovatif.

Masalahnya, konsep yang baik, tidak mudah diimplementasikan dengan baik, apalagi terkait dengan varian yang ada dalam sekolahsekolah kita, yang berbeda fasilitas, kualitas guru, kualitas kepemimpinan, dan juga kualitas informasi dan daya dukung.

Sebut saja, konsep 4C sebenarnya dimiliki juga oleh model pembelajaran yang dinamai active learning. Bila active learning bisa dijabarkan dengan baik maka Peserta Didik akan dilengkapi dengan ketrampilan komunikasi, kolaborasi, berpikir kritis dan pemecahan masalah, serta berpikir kreatif dan inovatif. Hal-hal tersebut yang didorong oleh guru ketika mereka melakukan active learning.

Ditarik lebih jauh lagi, bukankah 4C seharusnya muncul ketika pembelajaran IPA di sekolah menekankan student-centered dan bukan teacher-centered. Juga, bukankah pernah ada model yang disebut CBSA (Cara Belajar Peserta Didik Aktif). Semuanya itu mendorong terbangunnya ketrampilan 4C dalam diri para peserta didik.

Pentingnya tahap operasional pelaksanaan 4C pada pembelajaran IPA di sekolah-sekolah menengah pertama. Juga, sangat penting bagi Kemdikbud untuk melakukan pendampingan berkelanjutan dan kemudian pengawasan terkait pelaksanaan pembelajarna Peserta Didik aktif yang membekali Peserta Didik dengan 4C tersebut. Dengan langkah-langkah yang jelas tersebut,
Ketrampilan abad 21 ini sunguh-sungguh bisa dimiliki oleh Peserta Didik dan tidak akan terbatas dalam konsep yang bagus.

Begitu banyak kebijakan bagus yang sudah dikeluarkan. Namun, operasionalnya menjadi sulit karena diserahkan kepada sekolah dan kepada guru setempat. Karena kurang pengetahuan atau kurang waktu, sejumlah guru tidak mampu mengoperasionalkan konsep yang baik itu. Tetapi par guru IPA hanya menggantungkan metode dan strategi pembelajaran mereka pada buku pegangan atau dokumen-dokumen yang sudah mereka terima.

Sangat penting bahwa pemerintah mengubah strateginya dengan mengeluarkan dokumen yang lebih operasional terkait pelaksanaan 4C di sekolah, di kelas, dan untuk setiap bidang studi.

Langkah tersebut tidak akan membuat guru-guru kehilangan kreativitasnya. Justru, guru-guru akan memperoleh inspirasi mengenai implementasi pembekalan Ketrampilan Abad 21 itu. Mungkin, mulanya mereka hanya akan menggunakan apa yang ada dalam buku atau dokumen pemerintah itu. Namun, inspirasi dari buku itu, bisa mendorong guru untuk menerapkan langkah-langkah implementasi lain yang sejenis. Lama kelamaan, mereka akan menjadi biasa dan membuat varianvarian yang disesuaikan dengan konteks lokal.*

Ciri abad 21 menurut Kemendikbud adalah tersedianya informasi dimana saja dan kapan saja (informasi\}, adanya implementasi penggunaan mesin (komputasi\}, mampu menjangkau segala pekerjaan rutin (otomatisasi) dan bisa dilakukan dari mana saja dan kemana saja (komunikasi). Ditemukan bahwa dalam kurun waktu 20 tahun terakhir telah terjadi pergeseran pembangunan pendidikan ke arah ICT sebagai salah satu strategi manajemen pendidikan abad 21 yang di dalamnya meliputi tata kelola kelembagaan dan sumber daya manusia ( Soderstrom, From, Lovqvist, \& Tornquist, 2011) 1 . Abad ini memerlukan transformasi pendidikan secara menyeluruh sehingga terbangun kualitas guru yang mampu memajukan pengetahuan, pelatihan, ekuitas Peserta Didik dan prestasi Peserta Didik (DarlingHammond, 2006 ; Azam \& Kingdon, 2014).

Ciri abad 21 menurut Hernawan (dalam Hidayat dan Patras), meningkatnya interaksi antar warga dunia baik secara langsung maupun tidak langsung, semakin banyaknya informasi yang tersedia dan dapat diperoleh, meluasnya cakrawala intelektual, munculnya arus keterbukaan dan 
demokkratisasi baik dalam politik maupun ekonomi, memanjangnya jarak budaya antara generasi tua dan generasi muda, meningkatnya kepedulian akan perlunya dijaga keseimbangan dunia, meningkatnya kesadaran akan saling ketergantungan ekonomis, dan mengaburnya batas kedaulatan budaya tertentu karena tidak terbendungnya informasi.

Hidayat \& Patras selanjutnya menjelaskan kebutuhan pendidikan abad 21 menurut Patrick Slattery dalam bukunya yang berjudul "Curriculum Development In The Postmodern" yaitu pendidikan yang berdasarkan pada beberapa konsep berikut:

1. Pendidikan harus diarahkan pada perubahan sosial, pemberdayaan komunitas, pembebasan pikiran, tubuh dan spirit (mengacu pada konsep yang dikembangkan oleh Dorothy

2. Pendidikan harus berlandaskan pada 7 hal utama (mengacu pada konsep yang dikembangkan oleh Thich Nhat Hanh\}, yaitu tidak terikat pada teori, ideology, dan agama; jangan berpikir sempit bahwa pengetahuan yang dimiliki adalah yang paling benar; tidak memaksakan kehendak pada orang lain baik dengan kekuasaan, ancaman, propaganda maupun pendidik an; peduli terhadap sesama; jangan memelihara kebencian dan amarah; jangan kehilangan jatidiri; jangan bekerja di tempat yang menghancurkan manusia dan alam.

3. Konteks pembelajaran, pengembangan kurikulm dan penelitian diterapkan sebagai kesempatan untuk menghubungkan Peserta Didik dengan alam semesta (mengacu pada konsep yang dikembangkan oleh David Ort)

4. Membuat guru merasa sejahtera dalam kegiatan pembelajaran (mengacu pada konsep yang dikembangkan oleh Dietrich Bonhoeffer)

Pendidikan yang mengimplementasikan visi

21th century.

21 th century readiness merupakan kesiapan dalam menyambut abad 21. UNESCO telah membuat 4 (empat) pilar pendidikan untuk menyongsong abad 21, yaitu:
1. Learning to how (belajar untuk mengetahui)

2. Learning to do (belajar untuk melakukan)

3. Learning to be(belajar untuk mengaktualisasikan diri sebagai individu mandiri yang berkepribadian)

4. Learning to live together (belajar untuk hidup bersama)

Pendidikan yang membangun kompetensi "partnership 21st Century Learning" yaitu framework pembelajaran abad 21 yang menuntut peserta didik memiliki keterampilan, pengetahuan, dan kemampuan dibidang teknologi, media dan informasi, keterampilan pembelajaran, inovasi, keterampilan hidup dan

Kompetensi "partnership 21st Century Learning" mengacu pada format pendidikan abad 21 yang diusung oleh Hermawan (2006), yaitu:

1. Cyber (e-learning) dimana pembelajaran dilakukan dengan mengoptimalkan penggunaan

2. Open and distance learning dimana pembe lajara abad 21 dapat dilakukan dengan model pembelajaran jarak jauh, tidak terbatas dan dilakukan dengan memanfaatkan bantuan teknologi informasi dan komunikasi

3. Quantum Learning, yaitu menerapkan metode belajar yang disesuaikan dengan cara kerja

4. Cooperative Learning, yaitu pembelajaran yang menggunakan kelompok sebagai upaya menumbuhkan kerjasama antar

5. Society Technology Science, yaitu konsep interdisipliner yang diterapkan untuk mengintegrasikan permasalahan dalam ilmu pengetahuan, teknologi dan masyarakat.

6. Accelerated Learning, yaitu mengembangkan kemampuan dalam menyerap dan memahami informasi secara cepat sehingga dapat meningkatkan kemampuan belajar secara lebih efektif.

Para Guru yang memberikan pembelajaran IPA perlu membuka ruang kepada Peserta Didik untuk mengembangkan kreativitasnya. Kembangkan budaya apresiasi terhadap sekecil apapun peran atau prestasi Peserta Didik. Hal ini bertujuan untuk memotivasi Peserta Didik untuk terus meningkatkan prestasinya. Tentu kita ingat dengan Pak Tino Sidin, yang mengisi acara menggambar atau melukis di TVRI sekian tahun silam. Beliau selalu berkata "bagus" terhadap 
apapun kondisi hasil karya anak-anak didiknya. Hal tersebut perlu dicontoh oleh guru-guru masa kini agar Peserta Didik merasa dihargai.

Peran guru yang memberikan pembelajaran IPA hanya sebagai fasilitator dan membimbing setiap Peserta Didik dalam belajar, karena pada dasarnya setiap Peserta Didik adalah unik. Hal ini sesuai dengan yang disampaikan oleh Howard Gardner bahwa manusia memiliki kecerdasan majemuk. Ada delapan jenis kecerdasan majemuk, yaitu; (1) kecerdasan matematika-logika, (2) kecerdasan bahasa, (3) kecerdasan musikal, (4) kecerdasan kinestetis, (5) kecerdasan visual-spasial, (6) kecerdasan intrapersonal, (7) kecerdasan interpersonal, dan (8) kecerdasan naturalis.

Lalu bagaimana peran sekolah? Peranan sekolah dalam penerapan pembelajaran Abad 21 antara lain: a) Meningkatkan kebijakan \& rencana sekolah untuk mengembangkan keterampilan baru; b) Mengembangkan arahan baru kurikulum; c) Melaksanakan strategi pengajaran yang baru dan relevan, dan d) Membentuk kemitraan sekolah di tingkat regional, nasional dan internasional

Bagaimana ciri guru Abad 21 ? Menurut Ragwan Alaydrus,S.Psi, setidaknya ada 7 Karakteristik Guru Abad 21

1). Life-long learner. Pembelajar seumur hidup. Guru perlu meng-upgrade terus pengetahuannya dengan banyak membaca serta berdiskusi dengan pengajar lain atau bertanya pada para ahli. Tak pernah ada kata puas dengan pengetahuan yang ada, karena zaman terus berubah dan guru wajib up to date agar dapat mendampingi Peserta Didik berdasarkan kebutuhan mereka.

2). Kreatif dan inovatif. Peserta Didik yang kreatif lahir dari guru yang kreatif dan inovatif. Guru diharap mampu memanfaatkan variasi sumber belajar untuk menyusun kegiatan di dalam kelas.

3). Mengoptimalkan teknologi. Salah satu ciri dari model pembelajaran abad 21 adalah blended learning, gabungan antara metode tatap muka tradisional dan penggunaan digital dan online media. Pada pembelajaran abad 21, teknologi bukan sesuatu yang sifatnya additional, bahkan wajib.

4). Reflektif. Guru yang reflektif adalah guru yang mampu menggunakan penilaian hasil belajar untuk meningkatkan kualitas mengajarnya. Guru yang reflektif mengetahui kapan strategi mengajarnya kurang optimal untuk membantu Peserta Didik mencapai keberhasilan belajar. Ada berapa guru yang tak pernah peka bahkan setelah mengajar bertahun-tahun bahwa pendekatannya tak cocok dengan gaya belajar Peserta Didik. Guru yang reflektif mampu mengoreksi pendekatannya agar cocok dengan kebutuhan Peserta Didik, bukan malah terus menyalahkan kemampuan Peserta Didik dalam menyerap pembelajaran

5). Kolaboratif. Ini adalah salah satu keunikan pembelajaran abad 21. Guru dapat berkolaborasi dengan Peserta Didik dalam pembelajaran. Selalu ada mutual respect dan kehangatan sehingga pembelajaran akan lebih menyenangkan. Selain itu guru juga membangun kolaborasi dengan orang tua melalui komunikasi aktif dalam memantau perkembangan anak.

6). Menerapkan student centered. Ini adalah salah satu kunci dalam pembelajaran kelas kekinian. Dalam hal ini, Peserta Didik memiliki peran aktif dalam pembelajaran sehingga guru hanya bertindak sebagai fasilitator. Karenanya, dalam kelas abad 21 metode ceramah tak lagi populer untuk diterapkan karena lebih banyak mengandalkan komunikasi satu arah antara guru dan Peserta Didik.

7). Menerapkan pendekatan diferensiasi. Dalam menerapkan pendekatan ini, guru akan mendesain kelas berdasarkan gaya belajar Peserta Didik. pengelompokkan Peserta Didik di dalam kelas juga berdasarkan minat serta kemampuannya. Dalam melakukan penilaian guru menerapkan formative assessment dengan menilai Peserta Didik secara berkala berdasarkan performanya (tak hanya tes tulis). Tak hanya itu, guru bersama Peserta Didik berusaha untuk mengatur kelas agar menjadi lingkungan yang aman dan suportif untuk pembelajaran.

Lalu bagaimana kompetensi Peserta Didik pada abad 21 ? Setidaknya ada empat yang harus dimiliki oleh generasi abad 21, yaitu: ways of thingking, ways of working, tools for working and skills for living in the word. Bagaimana seorang pendidik harus mendesain pembelajaran yang akan menghantarkan peserta didik memenuhi kebutuhan abad 21. Berikut kemampuan abad 21 yang harus dimiliki peserta didik, yaitu:

1). Way of thinking, cara berfikir yaitu beberapa kemampuan berfikir yang harus dikuasai peserta didik untuk menghadapi dunia abad 21. Kemampuan berfikir tersebut diantaranya: kreatif, berfikir kritis, pemecahan masalah, pengambilan keputusan dan pembelajar.

2). Ways of working. kemampuan bagaimana mereka harus bekerja. dengan dunia 
yang global dan dunia digital. beberapa kemampuan yang harus dikuasai peserta didik adalah communication and collaboration. Generasi abad 21 harus mampu berkomunikasi dengan baik, dengan menggunakan berbagai metode dan strategi komunikasi. Juga harus mampu berkolaborasi dan bekerja sama dengan individu maupun komunitas dan jaringan. Jaringan komunikasi dan kerjasama ini memamfaatkan berbagai cara, metode dan strategi berbasis ICT. Bagaimana seseorang harus mampu bekerja secara bersama dengan kemampuan yang berbeda-beda.

3) Tools for working. Seseorang harus memiliki dan menguasai alat untuk bekerja. Penguasaan terhadap Information and communications technology (ICT) and information literacy merupakan sebuah keharusan. Tanpa ICT dan sumber informasi yang berbasis segala sumber akan sulit seseorang mengembangkan pekerjaannya.

4). Skills for living in the world. kemampuan untuk menjalani kehidupan di abad 21, yaitu: Citizenship, life and career, and personal and social responsibility. Bagaimana peserta didik harus hidup sebagai warga negara, kehidupan dan karir, dan tanggung jawab pribadi dan sosial.

Melalui pembelajaran abad 21, setidaknya ada dua keterampilan inti yang harus dkembangkan oleh para para guru yang memberikan pembelajaran IPA yakni: a) Kemampuan menggunakan pengetahuan IPA dan b) Berpikir kritis dan menyelesaikan masalah, komunikasi dan kerjasama, kreatifitas, kemandirian, dan lainnya untuk menjawab tantangan dunia nyata.

\section{Landasan Yuridis, filosofis, empirik, dan teoretis.}

Kurikulum 2013 dikembangkan berdasarkan landasan yuridis, landasan filosofis, landasan empirik, dan landasan teoretis. Landasan yuridis merupakan ketentuan hukum yang dijadikan dasar untuk pengembangan kurikulum. Landasan filosofis adalah landasan yang mengarahkan kurikulum kepada manusia apa yang akan dihasilkan kurikulum. Landasan empirik memberikan arahan berdasarkan pelaksanaan kurikulum yang sedang berlaku di lapangan. Landasan teoritik memberikan dasar-dasar teoritik pengembangan kurikulum sebagai dokumen dan proses.

\subsection{Landasan Yuridis}

Landasan yuridis kurikulum adalah Pancasila dan Undang-undang Dasar 1945,
Undang-undang nomor 20 tahun 2003 tentang Sistem Pendidikan Nasional, Peraturan Pemerintah Nomor 19 tahun 2005 tentang Standar Nasional Pendidikan, dan Peraturan Menteri Pendidikan Nasional Nomor 23 tahun 2006 tentang Standar Kompetensi Lulusan dan Peraturan Menteri Pendidikan Nasional Nomor 22 tahun 2006 tentang Standar Isi.Lebih lanjut, pengembangan Kurikulum 2013 diamanatkan oleh Rencana Pendidikan Pendidikan Menengah Nasional (RJPMN). Landasan yuridis pengembangan Kurikulum 2013 lainnya adalah Instruksi Presiden Republik Indonesia tahun 2010 tentang Pendidikan Karakter, Pembelajaran Aktif dan Pendidikan Kewirausahaan

\subsection{Landasan Filosofis}

Secara singkat kurikulum adalah untuk membangun kehidupan masa kini dan masa akan datang bangsa, yang dikembangkan dari warisan nilai dan prestasi bangsa di masa lalu, serta kemudian diwariskan serta dikembangkan untuk kehidupan masa depan. Ketiga dimensi kehidupan bangsa, masa lalu-masa sekarang-masa yang akan datang, menjadi landasan filosofis pengembangan kurikulum. Pewarisan nilai dan pretasi bangsa di masa lampau memberikan dasar bagi kehidupan bangsa dan individu sebagai anggota masyarakat, modal yang digunakan dan dikembangkan untuk membangun kualitas kehidupan bangsa dan individu yang diperlukan bagi kehidupan masa kini, dan keberlanjutan kehidupan bangsa dan warga negara di masa mendatang. Dengan tiga dimensi kehidupan tersebut, kurikulum selalu menempatkan peserta didik dalam lingkungan sosial- budayanya, mengembangkan kehidupan individu peserta didik sebagai warga negara yang tidak kehilangan kepribadian dan kualitas untuk kehidupan masa kini yang lebih baik, dan membangun kehidupan masa depan yang lebih baik lagi.

\subsection{Landasan Empiris}

Sebagai negara bangsa yang besar dari segi geografis, suku bangsa, potensi ekonomi, dan beragamnya kemajuan pembangunan dari satu daerah ke daerah lain, sekecil apapun ancaman disintegrasi bangsa masih tetap ada.Maka, kurikulum harus mampu membentuk manusia Indonesia yang mampu menyeimbangkan kebutuhan individu dan masyarakat untuk memajukan jatidiri sebagai bagian dari bangsa Indonesia dan kebutuhan untuk berintegrasi sebagai satu entitas bangsa Indonesia. Berbagai elemen masyarakat telah memberikan kritikan, komentar, dan saran berkaitan dengan beban belajar Peserta 
Didik, khususnya Peserta Didik sekolah dasar. Beban belajar ini bahkan secara kasatmata terwujud pada beratnya beban buku yang harus dibawa ke sekolah.Beban belajar ini salah satunya berhulu dari banyaknya matapelajaran yang ada di tingkat sekolah dasar. Maka, kurikulum pada tingkat sekolah dasar perlu diarahkan kepada peningkatan 3 (tiga) kemampuan dasar, yakni baca, tulis, dan hitung. Pada saat ini, upaya pemenuhan kebutuhan manusia telah secara nyata mempengaruhi secara negatif lingkungan alam. Pencemaran, semakin berkurangnya sumber air bersih adanya potensi rawan pangan pada berbagai belahan dunia, dan pemanasan global merupakan tantangan yang harus dihadapi generasi muda di masa kini dan di masa yang akan datang. Kurikulum seharusnya juga diarahkan untuk membangun kesadaran dan kepedulian generasi muda terhadap lingkungan alam dan menumbuhkan kemampuan untuk merumuskan pemecahan masalah secara kreatif terhadap isu-isu lingkungan dan ketahanan pangan.

Dengan berbagai kemajuan yang telah dicapai, mutu pendidikan Indonesia harus terus ditingkatkan. Hasil riset PISA (Program for International Student Assessment), studi yang memfokuskan pada literasi bacaan, matematika, dan IPA menunjukkan peringkat Indonesia baru bisa menduduki 10 besar terbawah dari 65 negara. Hasil Riset TIMSS (Trends in International Mathematics and Science Study) menunjukkan Peserta Didik Indonesia berada pada rangking amat rendah dalam kemampuan (1) memahami informasi yang komplek, (2) teori, analisis dan pemecahan masalah, (3) pemakaian alat, prosedur dan pemecahan masalah dan (4) melakukan investigasi. Hasil-hasil ini menunjukkan perlu ada perubahan orientasi kurikulum, yaitu tidak membebani peserta didik dengan konten namun mengutamakan pada aspek kemampuan esensial yang diperlukan semua warga negara untuk berperan serta dalam membangun negaranya pada abad 21 .

\subsection{LandasanTeoritis}

Kurikulum 2013 dikembangkan atas dasar teori "pendidikan berdasarkan standar" (standardbased education), dan teori kurikulum berbasis kompetensi. Pendidikan berdasarkan standar adalah pendidikan yang menetapkan standar nasional sebagai kualitas minimal warga negara untuk suatu jenjang pendidikan. Standar bukan kurikulum dan kurikulum dikembangkan agar peserta didik mampu mencapai kualitas standar nasional atau di atasnya. Standar kualitas nasional dinyatakan sebagai Standar Kompetensi Lulusan.Standar Kompetensi Lulusan mencakup sikap, pengetahuan, dan keterampilan.Standar Kompetensi Lulusan dikembangkan menjadi Standar Kompetensi Lulusan Satuan Pendidikan yaitu SKL SD/MI, SMP/MTs, SMA/MA, SMK/MAK.

Kompetensi adalah kemampuan seseorang untuk bersikap, menggunakan pengetahuan dan keterampilan untuk melaksanakan suatu tugas di sekolah, masyarakat, dan lingkungan dimana yang bersangkutan berinteraksi.Kurikulum berbasis kompetensi dirancang untuk memberikan pengalaman belajar seluas-luasnya bagi peserta didik untuk mengembangkan sikap, keterampilan dan pengetahuan yang diperlukan untuk membangun kemampuan yang dirumuskan dalam SKL.Hasil dari pengalaman belajar tersebut adalah hasil belajar peserta didik yang menggambarkan manusia dengan kualitas yang dinyatakan dalam SKL.

\section{Penutup}

Komunikasi adalah sebuah kegiatan mentransfer sebuah informasi baik secara lisan maupun tulisan. Namun, tidak semua orang mampu melakukan komunikasi dengan baik. Terkadang ada orang yang mampu menyampaikan semua informasi secara lisan tetapi tidak secara tulisan ataupun sebaliknya.

Komunikasi efektif tejadi apabila sesuatu (pesan) yang diberitahukan komunikator dapat diterima dengan baik atau sama oleh komunikan, sehingga tidak terjadi salah persepsi.supaya komunikasi antar manusia terjalin secara efektif dibutuhkan teknik berkomunikasi yang tepat. Teknik komunikasi adalah suatu cara yang digunakan dalam menyampaikan informasi dari komunikator ke komunikan dengan media tertentu. Dengan adanya teknik ini diharapkan setiap orang dapat secara efektif melakukan komunikasi satu sama lain dan secara tepat menggunakannya.

Kompetensi keterampilan Kolaborasi adalah kemampuan berkolaborasi atau bekerja sama, saling bersinergi, beradaptasi dalam berbagai peran dan tanggungjawab; bekerja secara produktif dengan yang lain; menempatkan empati pada tempatnya; menghormati perspektif berbeda. Kolaborasi juga memiliki arti mampu menjalankan tanggung jawab pribadi dan fleksibitas secara pribadi, pada tempat kerja, dan hubungan 
masyarakat; menetapkan dan mencapai standar dan tujuan yang tinggi untuk diri sendiri dan orang lain; memaklumi kerancuan.

Berpikir kritis dan pemecahan masalah adalah kemampuan untuk memahami sebuah masalah yang rumit, mengkoneksikan informasi satu dengan informasi lain, sehingga akhirnya muncul berbagai perspektif, dan menemukan solusi dari suatu permasalahan. Critical thinking dimaknai juga kemampuan menalar, memahami dan membuat pilihan yang rumit; memahami interkoneksi antara sistem, menyusun, mengungkapkan, menganalisis, dan menyelesaikan masalah.

Kreativitas dan inovasi adalah kemampuan untuk mengembangkan, melaksanakan, dan menyampaikan gagasan-gagasan baru kepada yang lain; bersikap terbuka dan responsif terhadap perspektif baru dan berbeda. Kreativitas juga didefinisikan sebagai kemampuan seseorang dalam menciptakan penggabungan baru. Kreativitas akan sangat tergantung kepada pemikiran kreatif seseorang, yakni proses akal budi seseorang dalam menciptakan gagasan baru. Kreativitas yang bisa menghasilkan penemuan-penemuan baru (dan biasanya bernilai secara ekonomis) sering disebut sebagai inovasi.

Demikianlah paparan tentang konsep 4C yang diharapkan dapat terintegrasi dalam pembelajaran IPA pada kurikulum 2013 versi 2017. Pembelajaran IPA di tingkat satuan pendidikan SMP demikian merupakan pembelajaran yang terintegrasi dengan seluruh mata pelajaran. Proses pengemasannya dilakukan dengan wadah pengembangan perangkat pembelajaran sesuai tuntutan Kurikulum 2013 edisi revisi2017. Melalui upaya demikian, diharapkan kualitas sumber daya manusia Indonesia di masa yang akan datang akan semakin meningkat. Amin.

\section{Daftar Pustaka}

Asep Herry Hernawan, dkk, 2006. Pengembangan Kurikulum dan Pembelajaran. UT Departemen Pendidikan Nasional, Jakarta.

Edward de Bono. 2000. Pemikiran Baru Era Milenium, Penerbit Elex Kompatindo.

H.A.R.Tilaar. 1990. Pendidikan Dalam Pembangunan Nasional menyongsong Abad $X X I$, Balai Pustaka.

Hidayat, R \& Patras, Y. E.2013, Pendidikan Abad 21 dan Kurikulum 2013. Unpak https://pendidikkreatif.wordpress.com/2017/01/07/7 -karakteristik-guru-abad-21/ (diunduh hari Kamis 16 Maret 2017 pkl 2

J. Michael Spector, M. David Merrill Jan Elen, M.J. 2014, Handbook of Researc Handbook of Research on Educational Communications and Technology fourth Edition New York.

Kemendikbud, (2017). Pengantar Diskusi Penyusunan Pedoman dan Materi Gerakan Literasi Nasional untuk Guru. Jakarta: Kemendikbud.

Martello, J. (2002). ManyRoadsThroughMany Modes: BecomingLiterate in Early Childhood. In L. Makin and C. J. Diaz (eds), Literacies in Early Childhood: ChangingViews, ChangingPractice. Sydney: MacLennan\& Petty.

Morocco, C.C., etal. (2008).

SupportedLiteracyforAdolescents:

TransformingTeachingandContentLearningf or The Twenty-First Century. San Francisco: Jossey-Bass A WileyImprint.

Sutherland-Smith, W. (2002). WeavingtheLiteracy Web: Changes in ReadingfromPagetoScreen. ReadingTeacher, 55(7): 662-669.

TIM. 2014. Materi Pelatihan Implementasi Kurikulum 2013 Tahun 2014 Mata Pelajaran Matematika SMP/MTs: Jakarta: Pusat Pengembangan Profesi Pendidik Badan Pengembangan Sumber Daya Manusia Pendidikan Dan Kebudayaandan Penjaminan Mutu Pendidikan Kementerian Pendidikan Dan Kebudayaan.

Trilling, B. \& Fadel, C. (2009). 21st Century Skills: Learningfor Life in Our Times. San Francisco: Jossey-Bass A WileyImprint. 